\title{
An Association between Stock Index and Macro Economic Variables in Bangladesh
}

\author{
Shamil M. Al-Islam \\ Department of Economics, School of Business, Independent University, Bangladesh. \\ shamil@iub.edu.bd \\ Zaima Ahmed \\ Department of Finance, School of Business, Independent University, Bangladesh. \\ zaima.ahmed@iub.edu.bd
}

\begin{abstract}
The aim of this article is to explore whether certain macroeconomic variables such as industrial index, inflation, broad money, exchange rate and deposit rate as a proxy for interest rate are interlinked with Dhaka stock price index (DSEX index) precisely after the introduction of new index by Dhaka Stock Exchange (DSE) since January 2013. The data set considered consists of monthly observations, for a period of four years from January 2013 to June 2018. Findings from cointegration analysis suggests that DSEX and macroeconomic variables have a significant long run relationship.

Both (Engle and Granger ,1987) and (Johansen and Juselius, 1990) may not always reflect the true long run relationship between variables when number of observations are small thus ( Pesaran and Shin ,1995) and (Pesaran et al ,1996) proposed Autoregressive Distributed Lag (ARDL) approach to cointegration or bound procedure was explored to examine the existence of long run relationship among the variables despite the changes that was accompanied in the stock price index. The co integration results show that there is long run relationship between stock price index and other macroeconomic variable despite the changes that was incorporated in stock price index with the exclusion of certain industries, implying that all the variables move together in the long run.
\end{abstract}

\section{Keywords: DSEX, ARDL, CO-INTEGRATION}

\section{Introduction}

The past few decades have been an era of financialization. International Finance Corporation and the World Bank in concert with a number of developing countries took steps in the 1980s to establish and revive their stock markets in an endeavor to allocate and make efficient mobilization of financial capital. There has been a plethora of studies showing how a countries macroeconomic variables and stock price indices are inextricably linked and as a result determines the growth of capital market.

Bangladesh Stock market has experienced rapid growth since its inception. It might not be a very well-developed capital market as compared to its neighboring counterparts, but has been a 
strong avenue for investment and resource mobilization. The capital market of Bangladesh comprises of two stock markets Dhaka Stock Exchange (DSE) and Chittagong Stock Exchange (CSE). DSE stopped reporting DSE General Index (DGEN) and introduced two new indices which are known as the DSE Broad Index (DSEX) and DSE 30 Index (DS30) based on free float and S\&P methodology. Thus, DSEX is considered as benchmark index in DSE. Stocks considered in DSEX must have a float-adjusted market capitalization above 100 million BDT. In addition, if a current index constituent falls below the 100 million BDT threshold, but stays above 70 million BDT, then the stock remains in the index provided it also meets the other inclusion criteria.

There have been few studies to explore the relationship between stock price indices and macroeconomic variables in Bangladesh which considered general price index till the end of 2012, comprising of all enlisted companies. (Afzal and Hossain ,2011) employed co-integration test and Granger causality test using data spanning from July 2003 to October 2011 and examines the relationship between stock prices and certain macroeconomic variables. According to their analysis stock prices and M1, M2 and inflation rate reflected cointegrating relationship. Moreover, the study also establishes unidirectional causality running from stock market index to exchange rate and M1 in the short-run.

Similar study was carried out by (Ali ,2011) using data set for the period from January 1987 to December 2010. According to their analysis stock prices does not granger cause the following macroeconomic variables CPI, deposit interest rate, export receipt, GDP, investment, industrial production index, lending interest rate and national income deflator. A unidirectional causality is observed from DSI to broad money supply and total domestic credit. On the other hand a bidirectional causality from DSI to exchange rate, import payment and foreign remittances seems to exist. Another similar study by (Khan and Yousuf ,2013) assessed the effect of the following macroeconomic variables such as deposit interest rates, exchange rates, consumer price index (CPI), crude oil prices and broad money supply (M2) on the stock price index. The study uses monthly data from 1992-2011 and employs Cointegration analysis and VECM. A positive relationship is found to exist between stock price and interest rates, crude oil prices and money supply. However, exchange rate is found to be negatively related to stock prices and CPI is insignificant and has no influence on the stock price movement, in the long-run. They have further employed Impulse Response Function and Variance Decomposition which suggest that shocks to macroeconomic variables explain a small proportion of the forecast variance error of the DSI, but these effects persist for a long period.

This article investigates how certain macroeconomic variables such as industrial index, inflation, broad money, exchange rate and deposit rate as a proxy for interest rate and stock price indices are interlinked specifically after DSE introduced the new form of index such as DSEX since January 2013. Dhaka Stock Exchange (DSE) basically changed the total composition of market capitalization.

\section{Review of Literature}

Financial markets are profoundly linked to macroeconomic conditions. A number of studies both theoretical and empirical, have been conducted to prove that macroeconomic variables and financial market relate significantly. For example, (Fama and Schwert 1977) asserted this fact in their article that macroeconomic indicators influence stock return. Over the past few decades, there had been increased belief that activities in the real economy such as weak macroeconomic environment, poor policy-making and implementation have the potential of adverse impact on the capital market. For instance, in the past twenty years, as a result of weak macroeconomic fundamentals, emerging economies like Russia and Argentina, witnessed 
severe financial crises, culminating into higher market fluctuations and drastic fall in the stock market (Baffour , 2015)

(Ross ,1976) is the pioneer of the Arbitrage Pricing Theory (APT) which states that the return on financial asset can be explained by multiple risk factors. This theory was further analyzed by (Chen, Oll and Ross, 1986) as initially APT was unsuccessful to identify the exact factors to explain the variations in financial returns. Their new analysis identified a linear relationship suggesting returns on financial assets is a function of various macroeconomic variables. Similar analogy was realized by (Fama,1981) showing positive relationships existed between certain macroeconomic variables such as GNP, money supply, capital expenditure, industrial production, and the interest rate and stock returns but there was a negative relationship between stock returns and the inflation rate.

(Zhao, 1999) investigated the relationships between stock prices in the Chinese financial market and inflation and industrial production index from 1993 to 1998. His analysis suggested an inverse relation between inflation, expected growth in industrial output and the stock market. In an analysis by (Maysami et al, 2004) it is observed that interest and exchange rates had a long-term equilibrium relationship with the Singapore stock index but there was no proof of cointegration amongst them. Furthermore, they concluded that there is a significant positive cointegration between the stock markets of Singapore, Japanese (Nikkei) and the United States (Dow Jones).

(Rahman and Uddin, 2009) examined the interactions between stock prices and exchange rates in three South Asian countries - Bangladesh, India and Pakistan for the period January 2003 to June 2008 using Granger causality test. Their analysis suggested that there is no co-integration between stock prices and exchange rates. (Pal and Mittal, 2011) also assessed the existence of long-run relationship between the Indian capital markets and key macroeconomic variables. Their investigation suggests that each of the macroeconomic variables such as interest rates, inflation rate, exchange rates and gross domestic savings (GDS) has contributed to the indices differently. The Error Correction Model shows that the inflation influences both the Bombay Stock Exchange, Sensex and the S\&P CNX Nifty significantly. On the other hand, Interest rates significantly impacts the S\&P CNX Nifty only. The foreign exchange rate seems to have a impact particularly on BSE Sensex. No relationship could be associated between gross domestic savings and BSE Sensex and the S\&P CNX Nifty. On this similar notion Bhattacharya and (Mukherjee, 2002) assessed the causal relationships between the BSE Sensex and five macroeconomic variables employing the following tests, unit-root tests, cointegration and longrun Granger non-causality. Their major findings indicated no cointegration between the stock price and macroeconomic variables such as interest rate, money supply and national income. However, the industrial index of production does impact the stock price and a bi-directional causality exists between stock price and inflation

Researchers employ consumer price index (CPI) as a proxy for inflation. It could be used for diagnosing indirect effect of inflation. Researchers, academics, investors and policy makers have been quite fixated over the empirical association between rate of inflation and stock price indices. In theory inflation does not impact stock prices due to the fact that companies can pass on the cost and that the real interest rate used to calculate the present value of real cash flows by investors remains unchanged with rise in inflation (Raymond, 2009). However, if inflation is forecasted accurately then costs of doing business can be transferred thus, nominal cash flows remains unaffected by a general rise in prices. However, with rise in inflation, uncertainty also increases for which firms may not be able to anticipate the change in price as well. Some researchers have concluded a positive relationship between stock returns and inflation while 
some researchers argue otherwise. However, further researches argued that stock price returns are totally independent of any influence of inflation.

Money supply one of the most important macroeconomic variable is a measure of liquidity in an economy and any change in this variable will influence investment decisions of the individual investors. A rise in nominal money supply leads to a portfolio rebalancing toward other real assets, causing an upward pressure on stock prices (Barbic and Jurkic , 2011). However, this increase in nominal money supply might be regarded as an indicator of future inflation, which also impacts stock returns. Furthermore, it also leads to fall in real interest rate. As a result, firms face lower discount rates against future cash flows which eventually impacts their investment decision.

(Geske and Roll, 1983) states that out of the various macroeconomic variables, exchange rate influences the stock price through international trade (Geske and Roll, 1983). The nature of relationship between exchange rate and stock returns depends on whether a country is characterized by import or export dominance. According to (Ajayi and Mougoue ,1996) when currency depreciates, prices of stocks go down immediately and thus, it is expected that stock prices and exchange rate relate negatively. The reason behind this scenario is that when currency depreciates, higher inflation is predicted in the future, making future investments uncertain as investors become unsure about the growth potentials of companies. Thus affecting the quantity for stocks demanded.

(Burdekin and Redferin ,2009) proves that individuals respond to the real return on deposits and equity markets relative performance and risk perception. (De Bonde et al 2011) finding suggests that increasing deposit rate is an effective measure to curb the stock price developments during periods of high stock prices. For example, an increase in deposit rates would signal investors to move their investments to the money market, ceteris paribus, and a decline in interest rates would lead investors to act otherwise and put their funds in stocks offering a better reward.

Industrial Production Index is a measure of real output from manufacturing, mining, electric and gas industries. A number of researches has been carried out to test the correlation between stock price returns and Industrial Index of Production. Followin ( Fama ,1981), by adding proxy to industrial index of production (Schwert 1990) confirmed Fama's positive results with industrial index of production and other macroeconomic variables as stated above. He identified three plausible explanations for the strong correlation between stock prices and real economic activity. Firstly, stock prices may reflect information about future real activity way before it actually happens. Inherently it means that stock prices are a leading indicator for the well-being of the economy. Secondly, stock prices and real investment will be manipulated by changes in discount rate, however the output from real investment is not realized until after some time it is made. Finally, change in price may also be an indication of changes in wealth, which can affect the demand for consumption and investment goods.

Firms with smaller capitalization tend to perform poorly during recessions, especially on the onset of recessions (Switzer,2012). (Beck and Kunt ,2006) postulates that due to lack of capital and liquidity compared to large firms, small and medium firms are more vulnerable to default risk. A significant factor adversely impacting stock returns, and in the asset allocation has been attribute to inflation risk (Boudoukh and Richardson, 1993; Katzur and Spierdijk, 2010). Small firms tend to operate in more competitive environments, thus, giving them less pricing power compared to larger firms. This results in exposure and vulnerability to inflation risk and relatively higher inflation premium. (Donald,2005) noted that investing in smaller 
capitalization stock may offer the potential for greater long-term results, yet it may also be associated with greater price volatility due to the higher risk of failure.

This article considers DSEX index which consists of firms with capitalization of minimum BDT 100 million, thus excluding relatively smaller firms. It is of interest to see whether the findings from previous studies, which considered the general index comprising of all enlisted firms in Dhaka Stock Exchange, holds true for the newly constructed index and the data set considered in this article.

\section{Research Methodology}

The paper investigates the long run linkages between macroeconomic variables and stock price change in Bangladesh after Dhaka Stock Exchange introduced a new calculation for indices and dynamic adjustment of variables taking monthly data from January 2013 to March 2019 from the Bangladesh Bank, World Bank, Bangladesh Bureau of Statistics.. All the data have been converted into natural logarithm. Various time series econometric techniques have been applied. The study employs The Augmented Dickey-Fuller (ADF) test which is widely used to test for stationarity (Dickey, Fuller, 1979, 1981) and another test known as KPSS test by Kwiatkowski, Phillips, Schmidt, and Shin (KPSS) to check for stationarity under which the null hypothesis is reversing the hypothesis of Dickey Fuller approach. This tests asserts that data will appear stationary by default if there is little information about the sample. (Kwaitkowski et al, 1992). Both the test is conducted at individual variables in level $\log$ form and the first differenced $\log$ form. As for ADF If the log forms or first differenced log forms reject the null hypothesis (H0: series has a unit root), the time series is stationary. On the other hand for KPSS if the LM test is less than critical value we accept the null hypothesis of stationarity followed by and Johansen cointegration technique based VAR model and vector error correction model (VCEM). After confirming the order of integration of the variables through the unit root test the study conducted Johansen co-integration test which allows the testing of hypotheses about the equilibrium relationship between variables (Brooks, 2002). Given that sometimes for small datasets Johansen cointegration may not portray the true estimates, thus for further confirmation the paper has also examines the Autoregressive Distributed Lagged (ARDL) Model which can easily accommodate small observation of both $\mathrm{I}(0)$ and $\mathrm{I}(1)$ process.

\section{Unit Root Test}

A time series is stationary if its mean and variance do not vary systematically over time and the value of the covariance between two time period depends only on the distance or gap or lag between the periods and not the actual time at which the covariance is computed. Many approaches are taken to carry out unit root test. However, the study employs the unit root test, The Augmented Dickey-Fuller (ADF) test and stationarity test Kwiatkowski, Phillips, Schmidt, and Shin (KPSS) test.

\section{Augumented Dickey-Fuller (ADF)Unit Root Test}

This test is developed by Dickey and Fuller (1976 and 1979) to test whether the error term $\mu_{t}$ is correlated or not. ADF test follows the same asymptotic distribution as the Dickey Fulelr test, thus the same critical values are used to interpret the results.

Test for a unit root with a constant at level with a constant and trend

$$
\Delta \mathrm{y}_{\mathrm{t}}=\beta_{0}+\beta_{\mathrm{it}}+\psi \mathrm{y}_{\mathrm{t}-1}+\sum_{i=1}^{p} \alpha \Delta \mathrm{y}_{\mathrm{t}-1}+\mu_{\mathrm{t}}(\mathrm{Eq} 3)
$$

Test for a unit root with a constant at first difference

$$
\Delta \mathrm{yt}_{\mathrm{t}}=\beta_{0+} \mathrm{y}_{\mathrm{t}-1}+\sum_{i=1}^{p} \alpha_{i} \Delta \mathrm{y}_{\mathrm{t}-1}+\mu_{\mathrm{t}}(\mathrm{Eq} 4)
$$


where $y_{t}$ denotes the value of a variable at time period $t, \Delta y_{t}=y_{t}-y_{t-1} ; \beta_{0}$ is a constant term; $t$ is a linear trend and $\mu \mathrm{t}$ is an error term. The basic objective of this test is to examine null hypothesis of presence of unit root and alternative hypothesis of series is stationary.

\section{Kwiatkowski, Phillips, Schmidt, and Shin (KPSS) Test}

One of the most criticism that has been associated with unit root test is their power is low if the process is stationary but with a root close to the non-stationary boundary. Hence in order to avoid this limitation, Kwiatkowski, Phillips, Schmidt, and Shin (1992) (Kwiatkowski et al., 1992) proposed an alternative test- the stationary test. The null hypothesis of KPSS test is the time series is stationary against the alternative hypothesis of a unit root. The series is expressed as the sum of deterministic trend, random walk, and stationary error, and the test is the LM test of the hypothesis that the random walk has zero variance. The asymptotic distribution of the statistic is derived under the null and under the alternate that a series is difference stationary.

$$
\begin{gathered}
y_{\mathrm{t}}=\beta^{\prime} \mathrm{D}_{\mathrm{t}}+\mu_{\mathrm{t}}+\mathrm{u}_{\mathrm{t}}(\mathrm{Eq} 5) \\
\mu_{\mathrm{t}}=\mu_{\mathrm{t}-1}+\varepsilon_{\mathrm{t}}, \varepsilon_{\mathrm{t}} \sim \mathrm{WN}\left(0, \sigma_{\varepsilon}^{2}\right) \quad(\mathrm{Eq} 6)
\end{gathered}
$$

where $\mathrm{D}_{\mathrm{t}}$ contains deterministic components (constant or constant plus time trend), $\mathrm{u}_{\mathrm{t}}$ is $\mathrm{I}(0)$ and may be heteroskedastic. Notice that $\mu \mathrm{t}$ is a pure random walk with innovation variance $\sigma^{2} \varepsilon$. The null hypothesis that $\mathrm{yt}_{\mathrm{t}}$ is $\mathrm{I}(0)$ is formulated as $\mathrm{H}_{0}: \sigma^{2} \varepsilon=0$, which implies that $\mu \mathrm{t}$ is a constant. Although not directly apparent, this null hypothesis also implies a unit moving average root in the ARMA representation of $\triangle y_{t}$. The KPSS test statistic is the Lagrange multiplier (LM) or score statistic for testing $\sigma_{\varepsilon}^{2}=0$ against the alternative that $\sigma^{2} \varepsilon>0$ and is given by

$$
\mathrm{T}^{-2}\left(\sum_{t=1}^{T} \hat{\mathrm{S}}^{2} \mathrm{t}\right) / \lambda \quad(\text { Eq } 7)
$$

\section{Cointegration test}

Regression analysis suggest that if one non stationary variable $s$ regressed on another non stationary variable it will usually lead to an incorrect estimate or sometimes will lead to no causal relationship at all. However, there may be some non stationary variables when linearly combination becomes stationary and is said to be cointegrated. Cointegration is an econometric tool used to examine the correlation between two stationary non time series variables. In practice, many economic series which are non-stationary in nature move together over time. This means that, although the variables under consideration may drift away from equilibrium for a while, there exist some forces on the series that make them converge upon some long-run value. Test of cointegration can be done by two-step Engle-Granger residual-based test and Johansen approach. However, before moving forward with cointegration test, the optimal lag length needs to be selected using information criteria such as such Akaike's (AIC) Schwarz'sInformation Criteria (SIC) and Hannan-Quinn information criterion.

Engle and Granger (1987) deal with the case where there are only two variables in an equation $\mathrm{y}_{\mathrm{t}}$ and $\mathrm{x}_{\mathrm{t}}$, there can be at most cointegrating relationship between $\mathrm{yt}_{\mathrm{t}}$ and $\mathrm{x}_{\mathrm{t}}$ that is stationary. However, in case of multiple number of variables, $k$ there could potentially be upto $r$ linearly independent cointegrating relationships ( where $r \leq k-1$ ), Johansen's approach of cointegration is used. This approach uses Vector Autoregressive (VAR) framework which was popularized by $\operatorname{Sim}(1980)$. A VAR is a systems of regression model that is there is more than one dependent variables. The Johansen cointegration tests and estimations are carried out by restricting a vector autoregressive (VAR) model. Suppose that a set of $k$ variables $(k \geq 2)$ are non-stationary and is and I(1) process and they are thought to be cointegrated. A vector autoregressive (VAR) model with $\mathrm{m}$ lags containing these variables could be set up:

$$
\mathrm{yt}_{\mathrm{t}}=\beta_{1} \mathrm{yt}_{\mathrm{t}-1}+\beta_{2} \mathrm{yt}_{\mathrm{t}-2}+\ldots . .+\beta_{\mathrm{m}} \mathrm{yt}_{\mathrm{t}-\mathrm{m}}+\mu_{\mathrm{t}} \quad(\mathrm{Eq} 8)
$$


where $Y t$ is an $\mathrm{N} \times 1$ column vector of dependent variables which are integrated of order one. $\mu \mathrm{t}$ denotes an $\mathrm{N} \times 1$ column vector of innovations.

Thus in order to use the Johansen test, the VAR above needs to transformed into a vector error correction model (VECM) by the reason that VECM releases the stationarity requirement of data. The VECM contains first difference terms and cointegration relationships and can be written as below:

$$
\begin{gathered}
\Delta \mathrm{y}_{\mathrm{t}}=\Gamma \Pi_{\mathrm{yt}-\mathrm{m}}+\Gamma 1 \Delta \mathrm{y}_{\mathrm{t}-1}+\Gamma 2 \Delta \mathrm{y}_{\mathrm{t}-2}+\ldots . . \Gamma \mathrm{m}-1 \Delta \mathrm{y}_{\mathrm{t}-(\mathrm{m}-1)}+\mu_{\mathrm{t}} \quad(\mathrm{Eq} 9) \\
\text { Where, } \Pi=\left(\sum_{j=1}^{m} \beta_{\mathrm{i}}\right)-\mathrm{I}_{\mathrm{g}} \text { and } \Gamma_{\mathrm{i}}=\left(\sum_{j=1}^{m} \beta_{\mathrm{j}}\right)-\mathrm{Ig}_{\mathrm{g}}(\mathrm{Eq} 10)
\end{gathered}
$$

The long-run cointegrating matrix of $\Pi$ determines the number of cointegrating vectors, say, r.Thus, the Johansen test focuses on the examination of coefficient matrix $\Pi$.

There are two test statistics under the Johansen cointegration approach which are called trace statistic and maximum eigen value. Trace statisctic is a joint test where he null hypothesis of at most $\mathrm{r}$ cointegrating vectors against the alternative hypothesis of more than $\mathrm{r}$ cointegrating vectors is tested. The null hypothesis of $r$ cointegrating vector against the alternative of $r+1$ is tested by maximizing eigenvalues statistic.

With small sample size (Engle and Granger 1987) and (Johansen and Juselius ,1990) may not always reflect the correct estimates. It become imperative to explore (Pesaran and Shin ,1995) and ( Pesaran et al 1996b) proposed Autoregressive Distributed Lag (ARDL) approach to cointegration or bound procedure for a longrun relationship, irrespective of whether the underlying variables are $\mathrm{I}(0), \mathrm{I}(1)$ or a combination of both. In such situation, the application of ARDL approach to cointegration will give realistic and efficient estimates. Unlike the Johansen and Juselius(1990) cointegration procedure, Autoregressive Distributed Lag (ARDL) approach to cointegration helps in identifying the cointegrating vector(s). That is, each of the underlying variables stands as a single long run relationship equation. If one cointegrating vector is identified, the ARDL model of the cointegrating vector is reparameterized into ECM

The ARDL(p,q1,q2...... $\mathrm{qk})$ model specification is given as follows;

$$
\begin{gathered}
\Phi(\mathrm{L}, \mathrm{p}) \mathrm{yt}=+\delta w \mathrm{t}+\mathrm{ut} 1, \text { iiikitLqx } \beta=\Sigma \quad(\mathrm{Eq} 11) \\
\text { where } \\
\Phi(\mathrm{L}, \mathrm{p})=1-\Phi 1 \mathrm{~L}-\Phi 2 \mathrm{~L} 2-\ldots .-\Phi \mathrm{pLp} \\
\beta(\mathrm{L}, \mathrm{q})=1-\beta 1 \mathrm{~L}-\beta 2 \mathrm{~L} 2-\ldots .-\beta \mathrm{qLq}, \text { for } \mathrm{i}=1,2,3 \ldots \ldots . \mathrm{k}, \mathbf{u t} \sim \operatorname{iid}(0 ; \delta 2) .
\end{gathered}
$$

$\mathrm{L}$ is a lag operator such that Loyt $=\mathrm{Xt}, \mathrm{L} 1 \mathrm{yt}=\mathrm{yt}-1$, and $\mathrm{Wt}$ is a $\mathrm{s} x 1$ vector of deterministic variables such as the intercept term, time trends, seasonal dummies, or exogenous variables with the fixed lags. $\mathrm{P}=0,1,2 \ldots, \mathrm{m}, \mathrm{q}=0,1,2 \ldots, \mathrm{m}, \mathrm{i}=1,2 \ldots, \mathrm{k}$ : namely a total of $(\mathrm{m}+1) \mathrm{k}+1$ different ARDL models. The maximum lag order, $m$, is chosen by the user. Sample period, $t=m+1, m+2 \ldots, n$.

\section{Results and Discussion}

\section{Unit Root}

The table below shows the unit root analysis where ADF test and KPSS test was used to check for stationarity. The null hypothesis of presence of unit root at level, in the ADF test, can not be rejected for all variables except for money supply while; similar results are obtained from KPSS test . However at first difference all variables are found to be stationary at $5 \%$ level under both tests. Having stationary variables (at first difference) allows to test for cointegration. 
Table:1 Unit Root Test

\begin{tabular}{|l|r|r|r|r|r|}
\hline VARIABLES & \multicolumn{3}{|c|}{ ADF TEST } & \multicolumn{3}{|c|}{ KPSS TEST } \\
\hline ldr & $5 \%$ & $\mathrm{t}$ & Probab & LM STAT & $5 \%$ \\
\hline dldr & -3.47937 & -0.59542 & 0.975 & 0.146 & 0.134257 \\
\hline Lii & -2.90621 & -5.21502 & 0 & 0.463 & 0.230111 \\
\hline dlii & -3.49215 & -1.18401 & 0.904 & 0.146 & 0.162125 \\
\hline lms & -2.91452 & -8.21217 & 0 & 0.146 & 0.369391 \\
\hline dlms & -3.47831 & -8.66141 & 0 & 0.463 & 0.092935 \\
\hline lgdse & -2.90842 & -7.1489 & 0 & 0.146 & 0.5 \\
\hline Dlgdse & -3.47831 & -2.68636 & 0.2455 & 0.146 & 0.109926 \\
\hline Linf & -2.90621 & -7.50748 & 0 & 0.146 & 0.073658 \\
\hline Dlinf & -3.47831 & -1.90879 & 0.6389 & 0.146 & 0.162594 \\
\hline Ler & -2.90621 & -7.70836 & 0 & 0.463 & 0.074105 \\
\hline Dler & -3.47831 & -1.81674 & 0.6856 & 0.146 & 0.260124 \\
\hline
\end{tabular}

Normality Test

Normality test has been carried out to ensure stability of the model ensuring that the distribution of residuals is normal. The Jarque-Bera test, a type of Lagrange multiplier test, is used to test for normality, heteroscedasticy, and serial correlation (autocorrelation) of regression residuals (Jarque and Bera 1980). The Jarque-Bera statistic is computed from skewness and kurtosis and asymptotically follows the chi-squared distribution with two degrees of freedom

Table: 2 Skewness

\begin{tabular}{|c|c|c|c|c|}
\hline Component & Skewness & Chi-sq & Df & Prob. \\
\hline 1 & 0.189983 & 0.360934 & 1 & 0.548 \\
\hline 2 & -0.06998 & 0.048969 & 1 & 0.8249 \\
\hline 3 & 0.117406 & 0.137841 & 1 & 0.7104 \\
\hline 4 & 0.003822 & 0.000146 & 1 & 0.9904 \\
\hline 5 & 0.067739 & 0.045885 & 1 & 0.8304 \\
\hline 6 & 0.203078 & 0.412407 & 1 & 0.5208 \\
\hline Joint & & 1.006183 & 6 & 0.9854 \\
\hline
\end{tabular}

Table: 3 Kurtosis

\begin{tabular}{|r|r|r|r|r|}
\hline Component & \multicolumn{1}{|l}{ Kurtosis } & \multicolumn{1}{l|}{ Chi-sq } & \multicolumn{2}{l|}{ Prob. } \\
\hline & & & & \\
\hline $\mathbf{1}$ & 3.841036 & 1.768356 & 1 & 0.1836 \\
\hline $\mathbf{2}$ & 3.025634 & 0.001643 & 1 & 0.9677 \\
\hline $\mathbf{3}$ & 2.448255 & 0.761056 & 1 & 0.383 \\
\hline $\mathbf{4}$ & 3.056452 & 0.007967 & 1 & 0.9289 \\
\hline $\mathbf{5}$ & 3.050556 & 0.00639 & 1 & 0.9363 \\
\hline $\mathbf{6}$ & 3.280664 & 0.196931 & 1 & 0.6572 \\
\hline & & & & 6 \\
\hline Joint & & 2.742342 & & 0.8404 \\
\hline
\end{tabular}


Table: 4 Jarque-Bara

\begin{tabular}{|c|c|c|c|}
\hline \multicolumn{1}{|c|}{ Component } & & df & Prob. \\
\hline & & & \\
\hline $\mathbf{2}$ & 2.12929 & 2 & 0.3449 \\
\hline $\mathbf{3}$ & 0.050612 & 2 & 0.975 \\
\hline $\mathbf{4}$ & 0.898897 & 2 & 0.638 \\
\hline $\mathbf{5}$ & 0.008113 & 2 & 0.996 \\
\hline $\mathbf{6}$ & 0.052275 & 2 & 0.9742 \\
\hline & 0.609338 & 2 & 0.7374 \\
\hline & & & 12 \\
\hline Joint & 3.748525 & & 0.9876 \\
\hline
\end{tabular}

\section{Cointegration test}

In order to carry out the Johansen test deciding the appropriate lag length is important. Given the data sample is very small, an unrestricted VAR is estimated (the model has sufficient $\mathrm{df}$ with 8 lags) to determine the appropriate lag length for all variables. Akaike Information Criteria suggest a lag length of 8 while the other criterions suggest a lag length of just 1 :

Table: 5 Lag Structure

\begin{tabular}{|c|c|c|c|c|c|c|}
\hline Lag & $\log L$ & LR & FPE & AIC & SC & HQ \\
\hline 0 & 396.3916 & NA & 8.99E-14 & -13.0131 & -12.8036 & -12.9311 \\
\hline 1 & 736.7477 & $601.2957^{*}$ & $3.55 \mathrm{e}-18^{*}$ & -23.1583 & $-21.69221^{*}$ & $-22.58481^{*}$ \\
\hline 2 & 761.5826 & 38.90805 & 5.34E-18 & -22.7861 & -20.0634 & -21.7211 \\
\hline 3 & 788.8326 & 37.24164 & $7.85 \mathrm{E}-18$ & -22.4944 & -18.5152 & -20.9379 \\
\hline 4 & 817.9848 & 34.01088 & 1.19E-17 & -22.2662 & -17.0303 & -20.2181 \\
\hline 5 & 864.0182 & 44.49897 & $1.19 \mathrm{E}-17$ & -22.6006 & -16.1081 & -20.0611 \\
\hline 6 & 920.2141 & 43.0835 & $1.08 \mathrm{E}-17$ & -23.2738 & -15.5247 & -20.2427 \\
\hline 7 & 998.0695 & 44.11809 & 7.09E-18 & -24.669 & -15.6633 & -21.1464 \\
\hline 8 & 1086.2 & 32.31469 & 7.19E-18 & $-26.40668^{*}$ & -16.1444 & -22.3925 \\
\hline
\end{tabular}

We employed Johansen cointegration test to find six cointegrating equations indicating long term relationship between the variables, where lag length chosen was based on AIC. Since the other criterions suggest just 1 lag in the VAR, which reduces to no lags in the cointegration test due to specification of the estimated equation containing differenced series.

Table: 6 Trace Statistics

\begin{tabular}{|c|c|c|c|c|}
\hline \multicolumn{2}{|l|}{ Hypothesized } & \multirow{2}{*}{$\begin{array}{l}\text { Trace } \\
\text { Statistic }\end{array}$} & \multicolumn{2}{|l|}{0.05} \\
\hline No. of CE(s) & Eigenvalue & & Critical Value & Prob. $^{* *}$ \\
\hline None * & 0.779089 & 260.8754 & 95.75366 & 0 \\
\hline At most $1^{*}$ & 0.657817 & 170.2757 & 69.81889 & 0 \\
\hline At most $2 *$ & 0.535049 & 105.9311 & 47.85613 & 0 \\
\hline At most 3 * & 0.432755 & 59.98172 & 29.79707 & 0 \\
\hline At most $4^{*}$ & 0.277191 & 25.96393 & 15.49471 & 0.0009 \\
\hline At most 5 * & 0.102482 & 6.487342 & 3.841466 & 0.0109 \\
\hline
\end{tabular}


Table: 7 Max Eigen Value

Hypothesized

\begin{tabular}{|l|r|r|r|r|}
\hline No. of CE(s) & \multicolumn{1}{l|}{ Eigenvalue } & \multicolumn{1}{l|}{ ltatistic } & \multicolumn{1}{l|}{ Critical Value } & \multicolumn{1}{l|}{ Prob. $^{* *}$} \\
\hline None & & & & \\
\hline At most 1 & 0.779089 & 90.59971 & 40.07757 & 0 \\
\hline At most 2 & 0.657817 & 64.34455 & 33.87687 & 0 \\
\hline At most 3 & 0.535049 & 45.94938 & 27.58434 & 0.0001 \\
\hline At most 4 & 0.432755 & 34.0178 & 21.13162 & 0.0005 \\
\hline At most 5 & 0.277191 & 19.47658 & 14.2646 & 0.0068 \\
\hline
\end{tabular}

According to the table above Max-eigenvalue test indicates 6 cointegrating equations at the 0.05 level.

The result shows that at every rank for the both trace statistics and maximum eigen values exceed the critical values at 5\% level indicating there are 6 cointegrating equations thus rejecting the null hypothesis of no cointegration at $5 \%$ level. Results indicating a full rank imply that the underlying relationship may be $\mathrm{I}(0)$ processes which can be estimated using VAR at level.

Table: 8 Cointegrating Equations

\begin{tabular}{|c|c|c|c|c|c|}
\multicolumn{6}{|c|}{ Normalized cointegrating coefficients (standard error in parentheses) } \\
\hline LOG(GDSE) & LOG(II) & LOG(INF) & LOG(ER) & LOG(DR) & LOG(MS) \\
\hline 1.000000 & 5.840234 & -1.115426 & 1.252466 & 0.816346 & -4.428242 \\
\hline & $(0.94046)$ & $(0.29127)$ & $(2.61878)$ & $(0.34123)$ & $(0.91378)$ \\
\hline
\end{tabular}

Table 8 shows the cointegrating relationship between stock price indices and macroeconomic variables. According to money demand theory inflation and stock return are inversely related as increased inflation rate brings about increased cost of living and as such, more resources are spent on consumption leading to less resource for investment. Thus it results a fall in the quantity of stock demanded and traded. Furthermore, the Dividend Discount theory has also explained how inflation and stock return apparently relate inversely. As stock performance is regarded as the discounted value of future dividend or cash flow, an appreciation in prices causes the risk free rate to rise resulting in the fall in value of prices of shares.

A number of studies conducted have established that money growth has a negative effect on stock return (Rozeff 1974). According to the researcher's money supply is mostly unaccompanied by increased productivity, unleashes cycle of rising prices on the economy, which eventually reduces stock prices. Consequently, rational investors will diversify from holing financial assets such as stocks/shares to real or tangible assets.

Given that our dataset is very small to confirm our test and rationality of cointegation we have further carried out another approach the AutoRegressive Distributive Lagged (ARDL) model bound testing approach developed by Pearsan et al (2001). Consequently, ARDL cointegration technique is preferable when dealing with variables that are integrated of different order, $\mathrm{I}(0)$, $\mathrm{I}(1)$ or combination of the both and, robust when there is a single long run relationship between the underlying variables in a small sample size. The long run relationship of the underlying variables is detected through the F-statistic (Wald test). In this approach, long run relationship of the series is said to be established when the F-statistic exceeds the critical value band. The 
major advantage of this approach lies in its identification of the cointegrating vectors where there are multiple cointegrating vectors. However in presence of (I2) the process becomes invalid. According to Haug (2002) ARDL bounds testing approach is more suitable for small sample size and the short run and long run parameters are estimated simultaneously .

The ARDL representation of the stock market and macroeconomic variables can be constructed as:

$\Delta \mathrm{LGDSE}_{\mathrm{t}}=\lambda_{0}+\lambda_{1} \mathrm{LGDSE}_{\mathrm{t}-1}+\lambda_{2} \mathrm{INF}_{\mathrm{t}-1}+\lambda_{3} \mathrm{II}_{\mathrm{t}-1}+\lambda_{4} \mathrm{DR}_{\mathrm{t}-1}+\lambda_{5} \mathrm{MS}_{\mathrm{t}-1}+\lambda_{6} \mathrm{ER}_{\mathrm{t}-1}+\lambda_{7} \Delta \mathrm{LGDSE}_{\mathrm{t}-\mathrm{i}}+\lambda_{8} \Delta \mathrm{INF}_{\mathrm{t}-\mathrm{i}+}$ $\lambda_{9} \Delta \mathrm{III}_{\mathrm{t}-\mathrm{i}+} \lambda_{10} \Delta \mathrm{DR}_{\mathrm{t}-\mathrm{i}} \lambda_{11} \Delta \mathrm{MS}_{\mathrm{t}-\mathrm{i}}+\lambda_{12} \Delta \mathrm{ER}_{\mathrm{t}-\mathrm{i}}+\eta \mathrm{ECM}_{\mathrm{t}-1}+\varepsilon \mathrm{t}(9)$

In the above model, $\Delta$ is the first-difference operator, and $\lambda$ s indicate long run coefficients and short run coefficients are represented as the first difference. The hypothesis of no cointegration deals with H0: $\lambda 1=\lambda 2=\lambda 3=\lambda 4=\lambda 5=\lambda 6=\lambda 7=\lambda 8=0$ and H1: $\lambda 1 \neq \lambda 2 \neq \lambda 3 \neq \lambda 4 \neq \lambda 5 \neq \lambda 6 \neq \lambda 7$ $\neq \lambda 8 \neq 0$ is an alternative hypothesis of cointegration

Next step is to compare the calculated F-statistic with critical values from Narayan (2005) which were generated for small sample sizes of between 30 and 80 observations. One set assumes that all variables in the model are $\mathrm{I}(0)$ and the other set assumes they are all $\mathrm{I}(1)$. If the calculated Fstatistic exceeds the upper critical bounds value, then the $\mathrm{H} 0$ is rejected. If the F-statistic falls within the bounds then the test is inconclusive. Lastly, if the F-statistic falls below the lower critical bounds value, it implies that there is no co-integration.

Table:9 ARDL Bound Test for Co-integration

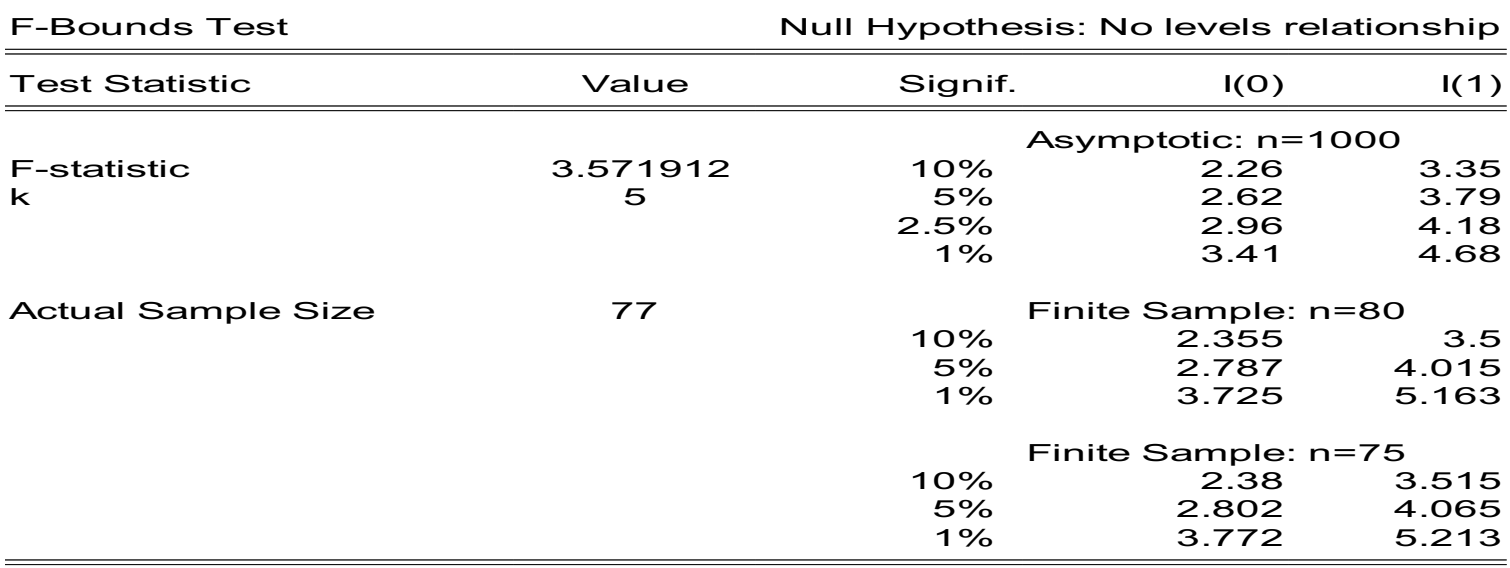

Therefore, the empirical findings lead to the conclusion that a long run relationship between stock market inflation rate, industrial index, deposit rate, money supply and exchange rate exists. Next step is to examine the marginal impacts of expected inflation, foreign interest rate and nominal effective exchange rate on nominal interest rate in Bangladesh

(Granger ,1988) demonstrates that causal relations among variables can be examined within the framework of ECM, with cointegrated variables. While the short run dynamics are captured by the individual coefficients of the lagged terms, the error correction term (ECT) contains the information of long run causality. Significance of lagged explanatory variable depicts short run causality while a negative and statistical significant ECT is assumed to signify long run causality. The short-run causality is thus determined from the following ARDL model;

$\Delta$ LGDSEt $_{\mathrm{t}}=\psi 0+\psi 1 \Delta \mathrm{LGDSE}_{\mathrm{t}-\mathrm{i}}+\psi 2 \Delta \mathrm{INF}_{\mathrm{t}-\mathrm{i}}+\psi 3 \Delta \mathrm{II}_{\mathrm{t}-\mathrm{i}}+\psi 4 \Delta \mathrm{DR}_{\mathrm{t}-\mathrm{i}}+\psi 5 \Delta \mathrm{MS}_{\mathrm{t}-\mathrm{i}} \psi 6 \Delta \mathrm{ER}_{\mathrm{t}-\mathrm{i}}+\eta \mathrm{ECMt}-1+\varepsilon \mathrm{t}$

where, $\Delta$ is the difference operator, ECM representing the error - correction term derived from the long-run cointegrating relation from the above specified ARDL models (10). In equation, $\eta$ 
should exhibit a negative and significant sign for causality to exist in the long run which is estimated and shown in the table below.

Table: 10 Error Correction Model estimates

\begin{tabular}{|l|l|l|}
\hline Lagged Variables & Coefficient & P value \\
\hline $\mathrm{D}($ LGDSE(-1)) & 1.0047 & 0.0002 \\
\hline $\mathrm{c}$ & 0.0064 & 0.3854 \\
\hline $\mathrm{D}($ LII $(-1))$ & 0.2021 & 0.00003 \\
\hline $\mathrm{D}(\mathrm{LINF}(-1))$ & 0.1518 & 0.3592 \\
\hline $\mathrm{D}($ LDR $(-1))$ & -0.0119 & 0.9096 \\
\hline $\mathrm{D}($ LMS $(-1))$ & -0.7779 & 0.1343 \\
\hline $\mathrm{D}($ LER(-1)) & 0.0957 & 0.9354 \\
\hline ECM $(-1))$ & -1.1389 & 0.0002 \\
\hline
\end{tabular}

$\mathrm{R}^{2}=0.263888$

F statistic $=3.482455(0.0030)$

We test for stability of the model by employing Breusch Godfrey test for Serial Correlation. And from the table below it can be seen that we cannot reject the null hypothesis of no serial correlation.

Table: 11

Breusch-Godfrey Serial Correlation LM Test:

Null hypothesis: No serial correlation at up to 1 lag

\begin{tabular}{llll}
\hline F-statistic & 3.801384 & Prob. F $(1,66)$ & 0.0555 \\
Obs*R-squared & 4.084500 & Prob. Chi-Square(1) & 0.0433 \\
\hline
\end{tabular}

Following (Narayan and Smyth ,2005), we employed (Pesaran and Pesaran 1997) to test for parameter stability. Once the error correction models have been estimated, ( Pesaran and Pesaran ,1997) suggest applying the cumulative sum of recursive residuals (CUSUM) and the CUSUM of square (CUSUMSQ) tests to assess the parameter constancy. Figures 1 and 2 plot the CUSUM and CUSUM of squares statistics for both long and short run .

Figure1: CUSUM Test

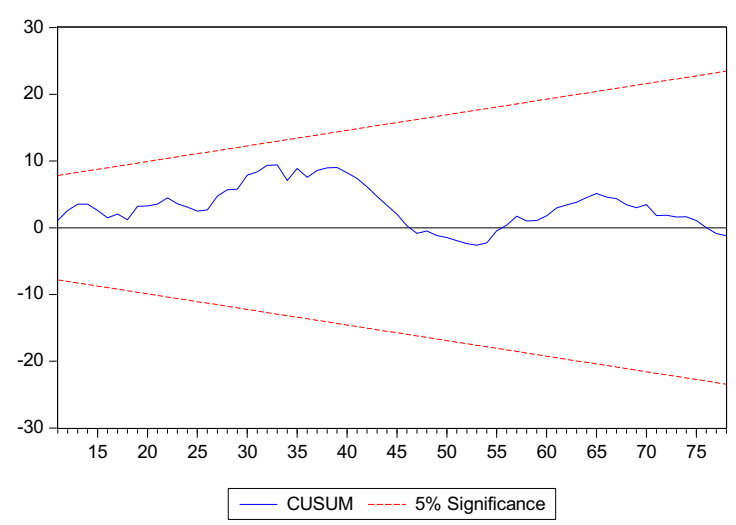

Figure 1 that the plot of CUSUM stays within the critical 5\% bounds that confirms the long-run relationships among variables and thus shows the stability of coefficient. 
Figure 2: CUSUM Square

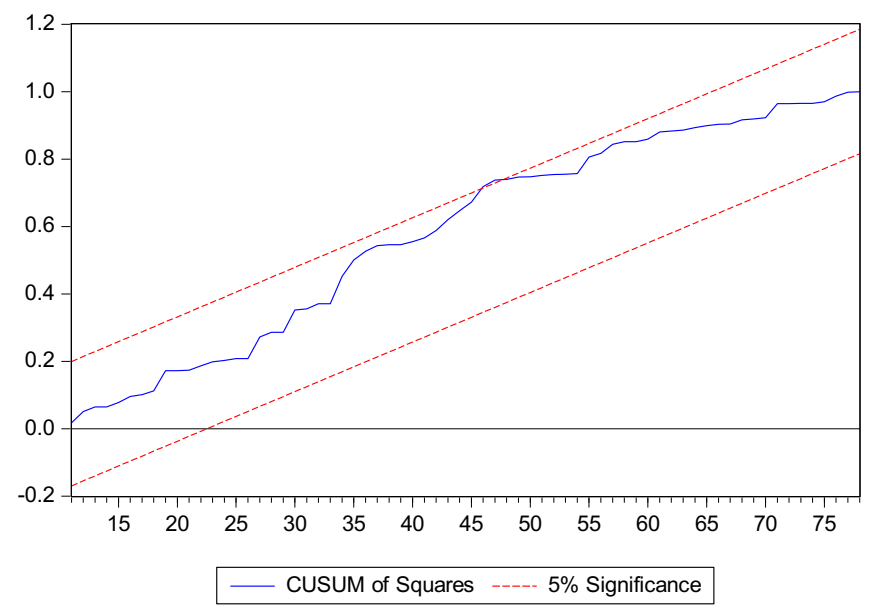

However, CUSUMSQ statistics exceed slightly the $5 \%$ critical bounds of parameter stability, thus indicating slight instability of the coefficient.

\section{Conclusion}

This article is aimed to investigate the relationship between the Bangladesh stock price index and macroeconomic variables after a new index, DSEX, has been introduced by the Dhaka Stock Exchange - which considers firms with capitalization of a minimum of BDT 100 million and excludes the relatively smaller firms. The article explores how macroeconomic variables such as industrial index, inflation, broad money, exchange rate and deposit rate impact the stock index. According to the cointegration analysis the DSEX and macroeconomic variables have a significant long run relationship as revealed by the number of cointegrating vectors. With small sample size (Engle and Granger ,1987) and (Johansen and Juselius, 1990) may not always reflect the correct estimates. Hence we explored ( Pesaran and Shin,1995) and (Pesaran et al ,1996) proposed Autoregressive Distributed Lag (ARDL) approach to cointegration or bound procedure for a longrun relationship, irrespective of whether the underlying variables are I(0), I(1) or a combination of both which is our case. ARDL bound testing, vector error correction (VECM) in our analysis and also CUSUM and CUSUMSQ to test the stability of the model used. The cointegration results show that there is long run relationship between stock price index and other macroeconomic variable despite the changes that was incorporated in stock price index with the exclusion of certain industries, implying that all the variables move together in the long run. Although the change has occurred recently but it relationship among the variables still follows the theoretical foundations. Perhaps a structural change can be further explored to get a bigger picture of the change which we wish to explore.

\section{References}

Afzal, N., \& Hossain, S, 2011. An empirical analysis of the relationship between macroeconomic variables and stock prices in Bangladesh. The Bangladesh Development Studies: 95-105.

Ajayi, R. A., \& Mougoue,, M. (1996). On the dynamic relation between stock prices and exchange rates. Journal of Financial Research, 19(2), 193-207.

Alimi, R. S. (2014). ARDL bounds testing approach to Cointegration: A re-examination of augmented fisher hypothesis in an open economy. Asian Journal of Economic Modelling, 2(2), 103-114. 
BAFFOUR, S. G. (2016). Examining the relationship between macroeconomic variables and stock prices. Evidence from the Ghana stock exchange (Doctoral dissertation).

Barbic, T., \& Jurkic, I. C. (2011). Relationship between macroeconomic fundamentals and stock market indices in selected CEE countries. Ekonomski pregled, 62(3-4), 113-133.

Bank, B. Monthly Economic Trends. Dhaka, Bangladesh: Bangladesh Bank.

Beck, T., \& Demirguc-Kunt, A. (2006). Small and medium-size enterprises: Access to finance as a growth constraint. Journal of Banking \& finance, 30(11), 2931-2943.

Bhattacharya, B., \& Mukherjee, J. (2002). The nature of the causal relationship between stock market and macroeconomic aggregates in India: An empirical analysis. In 4th annual conference on money and finance, Mumbai (pp. 401-426).

Boudoukh, J., \& Richardson, M. (1993). Stock returns and inflation: A long-horizon perspective. The American economic review, 83(5), 1346-1355.

Burdekin, R. C., \& Redfern, L. (2009). Stock market sentiment and the draining of China's savings deposits. Economics letters, 102(1), 27-29.

De Bondt, G. J., Peltonen, T. A., \& Santabárbara, D. (2011). Booms and busts in China's stock market: Estimates based on fundamentals. Applied Financial Economics, 21(5), 287-300.

Donald. B (2005). Business wire, October 12,

Engle, R. F., \& Granger, C. W. (1987). Co-integration and error correction: representation, estimation, and testing. Econometrica: journal of the Econometric Society, 251-276.

Fama, E. F. (1981). Stock returns, real activity, inflation, and money. The American economic review, 71(4), 545-565.

Fama, E. F., \& Schwert, G. W. (1977). Asset returns and inflation. Journal of financial economics, 5(2), 115-146.

Ferson, W. E., \& Harvey, C. R. (1993). The risk and predictability of international equity returns. Review of financial Studies, 6(3), 527-566.Geske, R and Roll, R, 1983.The Fiscal and Monetary Linkage Between Stock Returns and Inflation. The Journal of Finance, Vol. 38: 133

Gunasekarage, A., Pisedtasalasai, A., \& Power, D. M. (2004). Macroeconomic influence on the stock market: evidence from an emerging market in South Asia. Journal of Emerging Market Finance, 3(3), 285-304.

Haug, A. A. (2002). Temporal aggregation and the power of cointegration tests: a Monte Carlo study. Oxford Bulletin of Economics and statistics, 64(4), 399-412.

Katzur, T., \& Spierdijk, L. (2010). Stock returns and inflation risk: implications for portfolio selection.

Maysami, R. C., Howe, L. C., \& Rahmat, M. A. (2005). Relationship between macroeconomic variables and stock market indices: Cointegration evidence from stock exchange of Singapore's all-S sector Indices. Jurnal Pengurusan (UKM Journal of Management), 24.

Mbulawa, S. (2015). Stock market performance, interest rate and exchange rate interactions in zimbabwe: A cointegration approach.

Narayan, P. K. (2005). The saving and investment nexus for China: evidence from cointegration tests. Applied economics, 37(17), 1979-1990. 
Narayan, P. K., \& Smyth, R. (2005). The residential demand for electricity in Australia: an application of the bounds testing approach to cointegration. Energy policy, 33(4), 467-474.

Pal, K., \& Mittal, R. (2011). Impact of macroeconomic indicators on Indian capital markets. The journal of risk finance, 12(2), 84-97.

Im, K. S., Pesaran, M. H., \& Shin, Y. (1995). Testing for unit roots in dynamic heterogeneous panels. Department of Applied Economics working paper, 9526.

Pesaran, M. H., Shin, Y., \& Smith, R. J. (1996). Testing for the'Existence of a Long-run Relationship' (No. 9622). Faculty of Economics, University of Cambridge..

Pesaran, M. H., Shin, Y., \& Smith, R. J. (2001). Bounds testing approaches to the analysis of level relationships. Journal of applied econometrics, 16(3), 289-326.

Rahman, M. L., \& Uddin, J. (2009). Dynamic relationship between stock prices and exchange rates: Evidence from three South Asian countries. International Business Research, 2(2), 167174.

Raymond, K. (2009). Is there a long run relationship between stock prices and monetary variables? Evidence from Jamaica. Financial Stability Department Bank of Jamaica.

Rozeff, M. S. (1974). Money and stock prices: Market efficiency and the lag in effect of monetary policy. Journal of financial Economics, 1(3), 245-302.

Schwert, G. W. (1990). Stock returns and real activity: A century of evidence. The Journal of Finance, 45(4), 1237-1257.

Statistics, B. B. O. (2019) Statistical Yearbook of Bangladesh. Statistics Division, Ministry of Planning, Dhaka, Government of the People's Republic of Bangladesh.

Switzer, L. N. (2012). The Relative Performance of Small Cap Firms and Default Risk across the Business Cycle: International Evidence. international Journal of Business, 17(4).

Wooldridge, J. M. (2016). Introductory econometrics: A modern approach. Nelson Education.

World Bank. International Economics Dept. Development Data Group. (2019). World development indicators. World Bank.

Zhao, X. Q. (1999). Stock prices, inflation and output: evidence from China. Applied Economics Letters, 6(8), 509-511. 